\title{
PENGARUH PENERAPAN MODEL PERSIAPAN MENGAJAR ROPES TERHADAP HASIL BELAJAR SISWA PADA MATA PELAJARAN IPS TERPADU (EKONOMI) DI SMP NEGERI 2 INDRALAYA SELATAN
}

\author{
Oleh : David Indriadi \\ (SMA NEGERI 2 INDRALAYA UTARA)
}

d4v1d0512@gmail.com

\begin{abstract}
Abstrak-Penelitian ini bertujuan untuk mengetahui Pengaruh Penerapan Model Persiapan Mengajar ROPES terhadap Hasil Belajar Siswa pada Mata Pelajaran IPS (Ekonomi) di SMP Negeri 2 Indralaya Selatan Tahun Ajaran 2011/2012. Metode yang digunakan dalam penelitian ini adalah metode deskriptif korelasional. Populasi dan sampel dalam penelitian ini adalah siswa kelas VIII. Teknik pengumpulan data yaitu dokumentasi,observasi dan tes. Hipotesis dalam penelitian ini adalah, $\mathrm{Ho}=$ Tidak Ada Pengaruh Penerapan Model Persiapan Mengajar ROPES terhadap Hasil Belajar Siswa pada Mata Pelajaran IPS (Ekonomi) di SMP Negeri 2 Indralaya Selatan Tahun Ajaran 2011/2012. Dan Ha=Ada Pengaruh Penerapan Model Persiapan Mengajar ROPES terhadap Hasil Belajar Siswa pada Mata Pelajaran IPS (Ekonomi) di SMP Negeri 2 Indralaya Selatan Tahun Ajaran 2011/2012. Dengan taraf signifikansi 5\% atau dengan taraf kepercayaan 95\%, dan kriteria pengujian hipotesis dalam penelitian ini adalah Terima Ha : Jika nilai $t_{\text {hitung }}>t_{\text {tabel }}$ atau tolak Ho, Terima $H o$ : Jika nilai $t_{\text {hitung }} \leq t_{\text {tabel }}$ atau tolak $H a$.
\end{abstract}

Kata Kunci: Model Persiapan Mengajar ROPES (Review, Overview, Presentation, Exercise, Summary), Hasil Belajar.

\begin{abstract}
This study aims to determine the effect of the implementation of the ROPES Teaching Preparation Model on Student Learning Outcomes in Social Studies (Economics) in SMP Negeri 2 Indralaya Selatan Academic Year 2011/2012. The method used in this study is the descriptive correlational method. The population and sample in this study were students of class VIII. Data collection techniques are documentation, observation and tests. The hypothesis in this study is, Ho = No Effect of Application of ROPES Teaching Preparation Model on Student Learning Outcomes in Social Studies (Economics) in SMP Negeri 2 Indralaya Selatan Academic Year 2011/2012. And Ha = There is an Effect of the Implementation of the ROPES Teaching Preparation Model on Student Learning Outcomes in Social Studies (Economics) in SMP Negeri 2 Indralaya Selatan Academic Year 2011/2012. With a significance level of 5\% or with a confidence level of 95\%, and the hypothesis testing criteria in this study are Accept Ha: If the value of $t$ count $>t$ table or reject Ho, Accept Ho: If the value of t count $\leq t$ table or reject $H a$.
\end{abstract}

Keywords: ROPES Teaching Preparation Model (Review, Overview, Presentation, Exercise, Summary), Learning Outcomes. 


\section{PENDAHULUAN}

Dalam proses pendidikan, kegiatan belajar di sekolah merupakan kegiatan pokok yang harus dipersiapkan sesempurna mungkin. Dengan demikian agar proses pendidikan tersebut mampu meningkatkan pemahaman peserta didik, diperlukan adanya persiapan mengajar sebagai acuan dalam pendidikan di sekolah. "Menurut Sudjana dalam Pramika (2016:29) hasil belajar adalah kemampuankemampuan yang dimiliki siswa setelah ia menerima pengalaman belajarnya." Berdasarkan informasi yang didapat dari guru bidang studi IPS (Ekonomi) SMP Negeri 2 Indralaya Selatan adalah masih rendahnya nilai tes hasil belajar siswa pada pelajaran IPS (Ekonomi). Guru merasa ada kekurangan dalam persiapan mengajar yang digunakan,dan langkah-langkah pembelajarannya masih banyak yang belum dipahami siswa, Jadi untuk itu guru perlu menambah variasi atau menambah pengetahuannya tentang alternatif lain dalam mempersiapkan bahan ajar. Merencanakan pengajaran dalam bentuk persiapan mengajar, membutuhkan keterampilan profesional guru dalam mencari dan menafsirkan kompetensi-kompetensi untuk mengimplementasikan kurikulum tersebut. Perencanaan pengajaran tersebut harus dilaksanakan secara sistematis, logis dan mudah dipahami peserta didik dalam mempelajari problem-problem pengajaran.

Memang belum ada format baku dalam penyusunan persiapan mengajar. Dengan demikian guru diharapkan adanya kreatifitas guru untuk dapat mengembangkan formatformat baru. Tidak perlu ada keseragaman format, karena pada hakikatnya silabus dan rencana pengajaran adalah "program" guru mengajar. Model Persiapan mengajar ROPES (Review, Overview, Presentation, Exercise, Summary) merupakan salah satu alternatif guru dalam mempersiapkan bahan ajarnya. Karena di dalam langkahlangkah penerapan ROPES ini tidak hanya guru yang dituntut aktif dalam kegiatan belajar, siswa juga berperan dalam menentukan metode atau model pembelajaran yang mereka senangi, sehingga tugas guru hanya mengarahkan apabila terjadi kelah pahaman dalam pelaksanaannya.

Dalam langkah-langkah persiapan mengajar ROPES terdapat langkah yang disebut overview yang artinya lebih dalam dari hanya mengulang atau mengingat materi lalu tetapi sudah masuk kepada pemberian kesempatan pada siswa untuk mengemukakan pendapatnya, sehingga siswa juga memahami kemana arah pembelajaran pada materi bukan hanya memahami materinya. Selain itu guru juga harus banyak menggali informasi baik dari media maupun buku sehingga langkah-langkah persiapan mengajar 
ini dapat berjalan dengan semestinya dan dapat menambahkan metode dan variasi model pembelajran baru di dalammnya sehingga dapat meningkatkan dan menambah keaktifan dan motivasi siswa dalam kegiatan belajar mengajar.

Dengan dasar inilah peneliti berkeinginan untuk mengadakan penelitian yang berjudul : “

Pengaruh Penerapan Model Persiapan Mengajar ROPES (Review, Overview, Presentation, Exercise, Summary) Terhadap Hasil Belajar Siswa Pada Mata Pelajaran IPS (Ekonomi) di SMP Negeri 2 Indralaya Selatan“. Adapun tujuan dalam penelitian ini adalah : untuk mengetahui pengaruh Penerapan Model Persiapan Mengajar ROPES (Review, Overview, Presentation, Exercise, Summary) terhadap Hasil Belajar Siswa pada Mata Pelajaran IPS (Ekonomi) di SMP Negeri 2 Indralaya Selatan.

\section{METODE PENELITIAN}

F.N. Kerlinger (dalam Arikunto, 2010:116) menyebut variabel sebagai sebuah konsep seperti halnya laki-laki dalam konsep jenis kelamin, insaf dalam konsep kesadaran.

Variabel dalam penelitian ini adalah : Variabel bebas $(\mathrm{X})=$ Penerapan ROPES (Review, Overview, Presentation, Exercise, Summary).
Variabel Terikat $(\mathrm{Y})=$ Hasil Belajar

1. Model Persiapan Mengajar ROPES (Review, Overview, Presentation, Exercise, Summary).

Model persiapan mengajar ROPES tidak mengkategorikan perencanaan pengajaran menjadi rencana semester, mingguan, dan harian. Akan tetapi Hunts menyebutnya rencana prosedur pembelajaran sebagai persiapan mengajar yang disebutnya model pembelajaran ROPES (Review, Overview, Presentation, Exercise, Summary). Model pembelajaran ini selanjutnya dapat dikembangkan dan dimodifikasi sebagai tugas kelompok siswa dalam upaya memberdayakan kemampuan belajar mandiri siswa dengan berpedoman pada kerangka pembelajaran kontekstual sebagaimana dijelaskan diatas melalui langkahlangkah sebagi berikut :

a. Review

Guru mencoba mengukur kesiapan siswa mempelajari materi dengan melihat pengalaman sebelumnya.

b. Overview

Guru menjelaskan program pembelajaran yang akan dilaksanakan dengan menyampaikan isi secara singkat dan strategi yang akan digunakan. 
c. Presentation

Proses pembelajaran

sebagaimana yang telah

direncanakan.

d. Exercise

Siswa mempraktikkan atau mengemukakan pandangan tentang materi pembelajaran yang telah diperoleh.

e. Summary (menyimpulkan)

\section{Hasil Belajar}

Hasil belajar adalah hasil yang dicapai oleh siswa setelah mengalami proses belajar yang ditunjukan dengan nilai atau angka yang diperoleh dari hasil tes. Dalam penelitian ini peneliti mengambil hasil belajar berupa soal essay sebanyak dua kali pada setiap pembelajaran.

\section{Arikunto}

mengatakan bahwa "Populasi adalah keseluruhan subjek penelitian. Populasi menurut Sugiyono adalah wilayah generalisasi yang terdiri dari objek atau subjek yang menjadi kuantitas dan karakteristik tertentu yang ditetapkan oleh peneliti untuk dipelajari dan kemudian ditarik kesimpulannya (Sugiyono, 2011: 55).

Memperhatikan beberapa pendapat tersebut yang menjadi populasi dalam penelitian ini adalah seluruh siswa kelas VIII SMP Negeri 2 Indralaya Selatan Kabupaten Ogan Ilir. Berdasarkan informasi dari guru mata pelajaran IPS (Ekonomi) maka populasi penelitian ada 142 orang siswa dan siswi di kelas kelas VIII SMP Negeri 2 Indralaya Selatan.

$$
\text { Sugiyono }
$$

mengatakan bahwa "Sampel adalah bagian dari jumlah dan karakteristik yang dimiliki oleh populasi tersebut."

Akan tetapi Nana Syaodih dalam buku Metode Penelitian Pendidikan menyatakan Kebutuhan sampel besar dapat dilakukan jika diharapkan syarat-syarat keabsahan secara statistik terpenuhi dalam analisis statistik, baik dalam hal pengujian instrument (validitas, reliabilitas, analisis butir soal), maupun dalam pengujian hipotesis, dituntut tingkat kepercayaan (level of confident) tertentu minimal $95 \%$ atau alpha 5\% (0,05) untuk mencapai kepercayaan tersebut dibutuhkan sampel besar (Nana Syaodih, 2010 : 262), Memperhatikan pendapat tersebut, peneliti memutuskan menjadikan seluruh populasi yang ada adalah merupakan sampel, yang dibagi dalam dua kelas eksperimen, dan 2 kelas kontrol yang dipilih secara acak, yang jumlahnya kelas ekperimen 71 siswa dan kelas kontrol 71 siswa.

Sukmadinata

(2010:52)

mengatakan bahwa "Metode penelitian adalah merupakan rangkaian cara atau pelaksanaan kegiatan penelitian yang didasari oleh asumsi-asumsi dasar, padanganpadangan filosofis dan ideologis, pertanyaan dan isu-isu yang 
dihadapi." Metode yang digunakan dalam penelitian ini adalah metode deskriptif korelasional. Sukmadinata (2010:56) mengatakan bahwa "Metode korelasional adalah untuk mengetahui hubungan suatu variabel dengan variabel-variabel lain.” Dengan desain penelitian ekperimen semu.

Penelitian ini dilakukan di kelas VIII pada semester genap tahun pelajaran 2011/2012. Pada penelitian ini, teknik pengumpulan data yatiu :

\section{Teknik Observasi}

Riduwan

(2011:76)

mengatakan bahwa "Observasi adalah melakukan pengamatan langsung ke objek penelitian untuk melihat dari dekat kegiatan yang dilakukan." Observasi yang dilakukan untuk mengamati keaktifan siswa belajar di kelas. Adapun kriteria keaktifan belajar siswa adalah terdapat pada tabel III.

Tabel 1. Kriteria Keaktifan Belajar Siswa

\begin{tabular}{|c|c|}
\hline Interval Keaktifan & Kategori \\
\hline $85-100$ & Sangat Aktif \\
$9-84$ & Aktif \\
$53-68$ & Cukup Aktif \\
$37-52$ & Kurang Aktif \\
$0-36$ & Sangat Kurang Aktif \\
\hline
\end{tabular}

Selama

berlangsung

kegiatan

dilakukan

pengamatan dengan menggunakan

lembar observasi terdiri dari 4 (Empat) indikator adalah :

Keterangan :

Indikator I : Aktivitas Visual

1. Membaca materi dan soal yang diberikan oleh guru.

2. Membaca dari sumber-sumber lain.

3. Memperhatikan teman yang sedang mengajukan pendapat.

Indikator II : Aktivitas Lisan

1. Mengajukan pendapat.

2. Menjawab pertanyaan yang diajukan oleh guru.
3. Bertanya tentang materi yang sedang dibahas.

Indikator III: Aktivitas Mendengarkan

1. Mendengarkan penjelasan dari guru.

2. Mendengarkan kelompok lain yang sedang mempersentasikan hasil kerja kelompok.

3. Mendengarkan pertanyaan yang disampaikan oleh guru dan temen.

Indikator IV : Aktivitas Menulis

1. Menulis ide-ide yang disampaikan oleh anggota kelompok. 
2. Menulis penjelasan guru.

3. Menulis kesimpulan materi yang dipelajari.

Untuk melihat keaktifan siswa selama pembelajaran adalah dengan memberikan tanda check ( $(\sqrt{ })$ pada tiap deskriptor di lembar observasi dan memberikan skor sebagai berikut:

Tidak ada deskriptor yang nampak bernilai 1, 1 deskriptor yang nampak bernilai 2, 2 deskriptor yang nampak bernilai 3, 3 deskriptor yang nampak bernilai 4

\section{Teknik Test}

Test dilakukan untuk mendapatkan data hasil belajar siswa pada mata pelajaran IPS (ekonomi) setelah diterapkan model persiapan mengajar ROPES selama proses pembelajaran. Bentuk test yang digunakan adalah soal pilihan ganda dan tes yang dilakukan yaitu tes akhir diberikan sebanyak 1 kali setelah pertemuan pertemuan ke tiga.

\section{Metode Dokumentasi}

Dokumen adalah catatan tertulis tentang berbagai kegiatan atau peristiwa masa lalu yang berkaitan dengan tempat penelitian (Joko Sulistyo, 2010).

\section{HASIL DAN PEMBAHASAN}

Hasil Penelitian

Penelitian ini dilaksanakan di SMP NEGERI 2 Indralaya Selatan yang berlokasi di jalan Tanjung Karangan Desa Tebing Gerinting Selatan Kecamatan Indralaya Selatan Kabupaten Ogan Ilir Propinsi Sumatera Selatan, dengan jumlah sampel 138 siswa yang terdiri dari 69 siswa untuk kelas VIII A dan VIII C ( Kelas Eksperimen ) dan 69 siswa untuk kelas VIII B dan VIII D ( Kelas Kontrol ). Penelitian ini dijadwalkan pada tanggal 19 April sampai 19 Mei.

SMP Negeri 2 Indralaya Selatan terletak di jalan Tanjung Karangan Desa Tebing Gerinting Selatan Kecamatan Indralaya Selatan Kabupaten Ogan Ilir Propinsi Sumatera Selatan, dengan nomor statistik sekolah 201610089802. SMP Negeri 2 Indralaya Selatan ini berdiri pada sejak tahun 1994.

Gedung SMP Negeri 2 Indralaya Selatan ini terletak di jalan Tanjung Karangan Desa Tebing Gerinting Selatan Kabupaten Ogan Ilir, sekolah ini berjarak sekitar 200 meter dari jalan raya. Sekolah ini agak jauh dari pemukiman penduduk dan dikelilingi oleh semak-semak. Sehingga sekolah ini jauh dari keramaian dan kebisingan. SMP Negeri 2 Indralaya Selatan ini dibelakangnya terdapat Puskesmas dan SMA Negeri 1 Indralaya Selatan, selain itu tak jauh dari 
sekolah ini terdapat SD Negeri 1 dan

2 Indralaya Selatan.

Tabel 2. Distribusi Prekuensi Keaktifan Belajar Siswa Kelas

Eksperimen Dan Kontrol

\begin{tabular}{|c|c|c|c|c|c|c|}
\hline \multirow[t]{2}{*}{ No } & \multirow{2}{*}{$\begin{array}{c}\text { Interval } \\
\text { dalam } \\
\text { persentase }\end{array}$} & \multicolumn{2}{|c|}{ Kelas Ekperimen } & \multicolumn{2}{|c|}{ Kelas Kontrol } & \multirow[b]{2}{*}{ Kriteria } \\
\hline & & $f$ & $\begin{array}{c}\text { Persentase } \\
(\%)\end{array}$ & $f$ & $\begin{array}{c}\text { Persentase } \\
(\%)\end{array}$ & \\
\hline 1 & $X \leq 36$ & - & - & - & - & Sangat kurang aktif \\
\hline 2 & $37<X \leq 52$ & 3 & 4,4 & - & - & Kurang aktif \\
\hline 3 & $53<X \leq 68$ & 30 & 43,4 & 50 & 72,5 & Cukup aktif \\
\hline 4 & $69<\mathrm{X} \leq 84$ & 36 & 52,2 & 19 & 27,5 & Aktif \\
\hline \multirow[t]{2}{*}{5} & $85<X \leq 100$ & - & - & - & - & Sangat aktif \\
\hline & $\sum$ & 69 & 100 & 69 & 100 & \\
\hline \multicolumn{2}{|c|}{ Rata-rata } & 68,34 & & & 49,59 & \\
\hline
\end{tabular}

Berdasarkan tabel diatas, dapat dilihat bahwa pada kelas eksperimen frekuensi tertinggi keaktifan belajar siswa berada pada kriteria " aktif " berjumlah 36 siswa dengan persntase $52,2 \%$ sedangkan pada kelas kontrol frekuensi tertinggi keaktifan siswa berada pada kriteria " cukup aktif “ berjumlah 50 siswa dengan persentase $\quad 72,5 \%$. Rata-rata keaktifan siswa pada kelas eksperimen adalah 63,34\% yang berada pada kriteria "cukup aktif “ lebih besar dari pada rata-rata pada kelas kontrol yaitu 49,59\% yang berada pada kriteria " kurang aktif ".

Jadi dari perbandingan nilai keaktifan siswa diatas antara kelas eksperimen dengan kelas kontrol, dapat diketahui bahwa kelas eksperimen yang diterapkan dengan model pembelajaran persiapan mengajar pembelajaran ROPES (Review, Overview, Presentation, Exercise, Summary) lebih aktif dibandingkan dengan siswa kelas kontrol yang tidak diajarkan dengan menggunakan model persiapan mengajar pembelajaran ROPES (Review, Overview, Presentation, Exercise, Summary) .

Perbandingan hasil belajar siswa kelas eksperimen dan kontrol dapat dilihat pada tabel 13 dibawah ini : 
Tabel 3. Distribusi Frekuensi Perbandingan Hasil Belajar Siswa Kelas Eksperimen Dan Kontrol

\begin{tabular}{|c|c|c|c|c|c|c|}
\hline \multirow{2}{*}{ No } & \multirow{2}{*}{ Interval } & \multicolumn{2}{|c|}{ Kelas Eksperimen } & \multicolumn{2}{|c|}{ Kelas Kontrol } & \multirow{2}{*}{ Kriteria } \\
\hline & & $f$ & Persentase & $f$ & Persentase & \\
\hline 1 & $86-100$ & 5 & 7,3 & - & - & Sangat baik \\
\hline 2 & $71-85$ & 8 & 11,5 & 6 & 8,7 & Baik \\
\hline 3 & $56-70$ & 48 & 69,6 & 22 & 31.9 & Cukup baik \\
\hline 4 & $41-55$ & 8 & 11,6 & 32 & 46,4 & Kurang \\
\hline 5 & $\leq 40$ & - & - & 9 & 13 & $\begin{array}{l}\text { Sangat } \\
\text { kurang }\end{array}$ \\
\hline$\Sigma$ & & 69 & 100 & 69 & 100 & \\
\hline & & & 66,23 & & 50.00 & \\
\hline
\end{tabular}

Berdasarkan tabel diatas, maka dapat dilihat bahwa pada kelas eksperimen frekuensi tertinggi hasil belajar siswa pada kriteria "cukup baik" berjumlah 48 siswa dengan persentase 69,6\% dan frekuensi belajar siswa pada kelas kontrol berada pada kriteria "kurang baik" berjumlah 32 siswa dengan persentase $39 \%$. Rata-rata hasil belajar kelas eksperimen mencapai 66,23 yang ada pada kriteria "cukup baik" lebih besar dari rata-rata kelas kontrol yaitu 50,00 yang berada pada kriteria "kurang baik".

Pada $\alpha \quad 0,05 \quad t_{\text {hitung }}(0,64) \leq$ $\mathrm{t}_{\text {tabel }}(1,67) \alpha 0,05 / 2$, maka tolak Ha dan terima Ho yang artinya tidak ada pengaruh Model persiapan mengajar ROPES (Review, Overview, Presentation, Exercise, Summary) terhadap Hasil belajar siswa di SMP Negeri 2 Indralaya Selatan.I

\section{Pembahasan}

Jadi dari perbandingan hasil belajar antara kelas eksperimen dengan kelas kontrol, dapat diketahui bahwa pada kelas eksperimen yang menggunakan persiapan mengajar pembelajaran ROPES (Review, Overview, Presentation, Exercise, Summary) siswanya cendrung mendapatkan hasil belajar yang lebih baik dari pada kelas kontrol yang tidak memakai model persiapan mengajar pembelajaran ROPES (Review, Overview, Presentation, Exercise, Summary) .

Berdasarkan analisis diatas, maka dapat diketahui hasil observasi keaktifan siswa dan hasil belajar siswa pada kelas eksperimen dan kelas kontrol.

Berdasarkan deskripsi hasil observasi pada kelas eksperimen yang menggunakan model pembelajaran persiapan mengajar pembelajaran ROPES (Review, Overview, Presentation, Exercise, Summary) diperoleh frekuensi tertinggi keaktifan belajar siswa berada pada kriteria " aktif “ berjumlah 36 siswa dengan persntase 
$52,2 \%$ sedangkan pada kelas kontrol frekuensi tertinggi keaktifan siswa berada pada kriteria " Kurang Aktif " berjumlah 50 siswa dengan persentase $72,5 \%$. Rata-rata keaktifan siswa pada kelas eksperimen adalah 66,34 pada kreteria "cukup aktif " lebih besar dari pada rata-rata pada kelas kontrol yaitu 49,59 pada kriteria "kurang aktif". Maka dengan demikian siswa dikelas eksperimen yang menggunakan model persiapan mengajar pembelajaran ROPES (Review, Overview, Presentation, Exercise, Summary) lebih aktif dibandingkan dengan siswa kelas kontrol yang tidak menggunakan model persiapan mengajar pembelajaran ROPES (Review, Overview, Presentation, Exercise, Summary).

Hasil tes menunjukkan bahwa pada kelas eksperimen frekuensi tertinggi hasil belajar siswa pada kriteria "cukup baik" berjumlah 48 siswa dengan persentase $69,6 \%$ dan frekuensi belajar siswa pada kelas kontrol berada pada kriteria "kurang baik" berjumlah 32 siswa dengan persentase $46,4 \%$. Rata-rata hasil belajar kelas eksperimen mencapai $66,23 \%$ yang ada pada kriteria "cukup baik" lebih besar dari ratarata kelas kontrol yaitu 50,00 yang berada pada kriteria "kurang baik".

Sedangkan berdasarkan analisis hasil tes mengenai hasil belajar siswa melalui uji-t maka diperoleh $t_{\text {hitung }}$ sebesar 0,64 sementara nilai $t_{\text {tabel }}$ pada tingkat keyakinan $95 \%$ dan derajat kebebasan 67 adalah sebesar 1,67. Dari hasil uji $\mathrm{t}$ dapat dinyatakan dengan nilai Pada $\alpha 0,05 \quad \mathrm{t}_{\text {hitung }}<$ $t_{\text {tabel }}$ atau $0,64<1,67$. Hal ini berarti bahwa variabel bebas yaitu Model Persiapan Mengajar ROPES (Review, Overview, Presentation, Exercise, Summary) tidak berpengaruh secara signifikan terhadap variabel terikat yaitu hasil belajar. Dengan demikian hipotesis Ha yang menyatakan ada pengaruh Model Persiapan Mengajar ROPES (Review, Overview, Presentation, Exercise, Summary) terhadap hasil belajar siswa pada mata pelajaran IPS Ekonomi di tolak dan hipotesis $\mathrm{H}_{0}$ yang menyatakan tidak ada pengaruh Model Persiapan Mengajar ROPES (Review, Overview, Presentation, Exercise, Summary) terhadap hasil belajar siswa pada mata pelajaran IPS Ekonomi diterima.

Adapun kendala-kendala yang dihadapi peneliti selama penelitian ini dalam menerapkan Model Persiapan mengajar ROPES (Review, Overview, Presentation, Exercise, Summary) ini adalah sebagai berikut:

1. Pada awal Model ROPES (Review, Overview, Presentation, Exercise, Summary) ini diterapkan guru mengalami kesulitan memotivasi siswa untuk membaca/ memahami materi pelajaran yang ada di buku dengan menggunakan langkah 
ROPES ini karena siswa terbiasa dengan metode ceramah dan media yang kurang dari guru sehingga siswa hanya menerima dari guru sehingga seluruh informasi berasal dari guru.

2. Ketika diberi pertanyaan di depan kelas pada langkah Summary (menyimpulkan) dari hasil yang dibaca tanpa melihat catatan, banyak siswa yang belum bisa menyimpulkan dari yang mereka pelajari saat itu.

3. Tahapan-tahapan dalam ROPES ini tidak diulang lagi oleh siswa di rumah, sehingga materi yang didapat di sekolah tidak terlalu terserap sempurna dikarenakan faktor-faktor lingkungan di luar yang kurang mendukung seperti kurangnya alat-alat media pencari informasi (internet) yang ada dilingkungan rumah siswa, sehingga minat siswa akan pengetahuan baru kurang sekali

Selain kendala-kendala tersebut, ada beberapa kelebihan dari Persiapan Mengajar ROPES ( Review, Overview, Presentation, Exercise, Summary) ini antara lain :

1. Siswa lebih aktif selama proses pembelajaran karena siswa lebih banyak mencari informasi

2. Mengembangkan kemampuan siswa dalam mencari garis besar dari suatu materi pelajaran yang sedang dipelajari, mengungkapkan pertanyaan, mencari jawaban atas pertanyaan yang muncul, dan menyimpulkannya.

3. Mendorong siswa untuk menjadi seorang pembaca aktif dan terarah langsung pada intisari atau kandungankandungan pokok yang tersirat dan tersurat dalam teks.

\section{KESIMPULAN DAN SARAN Kesimpulan}

Berdasarkan hasil perhitungan dan observasi pada saat penerapan Model Persiapan Mengajar ROPES (Review, Overview, Presentation, Exercise, Summary) maka dapat disimpulkan bahwa :

1. Keaktifan belajar siswa berada pada kriteria " aktif " berjumlah 36 siswa dengan persentase $52,2 \%$ sedangkan pada kelas kontrol frekuensi tertinggi keaktifan siswa berada pada kriteria " Kurang Aktif “ berjumlah 50 siswa dengan persentase $72,5 \%$. Rata-rata keaktifan siswa pada kelas eksperimen adalah 66,34 pada kreteria "cukup aktif " lebih besar dari pada rata-rata pada kelas kontrol yaitu 49,59 pada kriteria "kurang aktif"

2. Hasil tes menunjukkan bahwa pada kelas eksperimen frekuensi tertinggi hasil belajar siswa pada kriteria "cukup baik" berjumlah 48 siswa dengan persentase $69,6 \%$ dan frekuensi belajar siswa 
pada kelas kontrol berada pada kriteria "kurang baik" berjumlah 32 siswa dengan persentase $46,4 \%$. Rata-rata hasil belajar kelas eksperimen mencapai $66,23 \%$ yang ada pada kriteria "cukup baik" lebih besar dari ratarata kelas kontrol yaitu 50,00 yang berada pada kriteria "kurang baik".

3. Hasil analisis hasil tes mengenai hasil belajar siswa melalui uji-t maka diperoleh $t_{\text {hitung }}$ sebesar 0,64 sementara nilai $t_{\text {tabel }}$ pada tingkat keyakinan $95 \%$ dan derajat kebebasan 67 adalah sebesar 1,67. Dari hasil uji t dapat dinyatakan dengan nilai Pada $\alpha 0,05 \mathrm{t}_{\text {hitung }}<$ $t_{\text {tabel }}$ atau $0,64<1,67$. Hal ini berarti bahwa variabel bebas yaitu Model Persiapan Mengajar ROPES (Review, Overview, Presentation, Exercise, Summary) tidak berpengaruh secara signifikan terhadap variabel terikat yaitu hasil belajar. Dengan demikian hipotesis $\mathrm{H}_{0}$ yang menyatakan tidak ada pengaruh Model Persiapan Mengajar ROPES (Review, Overview, Presentation, Exercise, Summary) terhadap hasil belajar siswa pada mata pelajaran IPS Ekonomi diterima.

\section{Saran}

Berdasarkan kesimpulan di atas penulis mencoba memberikan saran yang mungkin bermanfaat yaitu :
1. Bagi guru, diharapkan agar dapat memberikan kesempatan lebih banyak kepada siswa untuk mengemukakan pendapatnya terhadap materi dan siswa dapat menggali informasinya sendiri dirumah dan mengembangkan metode-metode pembelajaran yang diterapkan di sekolah, dan guru memotivasi siswa untuk banyak-banyak membaca dirumah.

2. Bagi sekolah, diharapkan dapat lebih memperhatikan lingkungan sekitar sekolah sehingga apa yang diterapkan guru di kelas dapat terealisasi di lingkungan belajar siswa.

3. Bagi siswa, diharapkan pada saat proses belajar mengajar agar lebih aktif serta berani mengemukakan pendapat, menggali informasi lain tentang materi selain yang diberikan oleh guru dan bertanya tentang apa yang belum dipahami dari materi yang dipelajari.

4. Bagi kalangan akademisi, diharapkan dapat mengembangkan penelitian ini dengan menambah indikatorindikator keaktifan siswa dan menambah variabel terikat $(\mathrm{Y})$ yang berbeda.

\section{DAFTAR PUSTAKA}

Arikunto, Suharsimi. 2010. Dasardasar Evaluasi Pendidikan. Yogyakarta:Bumi Aksara 2010. Prosedur Penelitian suatu Pendekatan Praktik. Jakarta: Rineka Cipta 
Riduwan. 2011. Belajar Mudah

Penelitian untuk Guru-

Karyawan dan Peneliti

Pemula. Bandung: Alfabeta

Sugiyono. 2011. Metode Penelitian

Kuantitatif Kualitatif dan

$\boldsymbol{R} \& \boldsymbol{D}$. Bandung: Alfabeta

2011. Statistika untuk

Penelitian. Bandung: Alfabeta

Sukmadinata, Nana Syaodih. 2010.

Metode

Penelitian

Pendidikan. Bandung: PT Remaja Rosdakarya.

Pramika, Depi. (2018). Pengaruh

Penerapan Model

Pembelajaran Kooperatif Tipe

Artikulasi Terhadap Hasil

Belajar Siswa Pada Mata

Pelajaran Akuntansi Di SMK

Setia Darma Palembang.

Prosiding Revolusi Mental

Mewujudkan Tenaga

Pendidikan Yang Profesional

Dalam Menyiapkan Generasi

Emas Indonesia. Pada tanggal

17 Desember 2016.(Online)

https://jurnal.univpgri-

palembang.ac.id/index.php/pro

siding/article/view/1078

(diakses tanggal 15 April

2020). 